\title{
Serum Separator Tube
}

National Cancer Institute

\section{Source}

National Cancer Institute. Serum Separator Tube. NCI Thesaurus. Code C112825.

A blood collection tube that contains a gel that separates blood cells from serum. 